Joanna Błaszczak ๑ https://orcid.org/0000-0002-8332-2827

University of Wrocław

Juliane Domke

Max Planck Society - Social Neuroscience Lab

\title{
Can Tense Be Subject to Grammatical Illusion? Part 1: A Design of an ERP Study on the Processing of Tense and Aspect Mismatches in Compound Future Constructions in Polish
}

\begin{abstract}
This two-part paper is concerned with the processing of two types of compound future in Polish, with infinitival and participial complements. In the first part we present a design and predictions of an ERP study whose goal was to monitor the EEG correlates of two types of temporal mismatches: i) tense mismatches between the future auxiliary and the past tense modifier wczoraj ('yesterday') relative to the jutro ('tomorrow') baseline and ii) aspect mismatches between the future auxiliary and the perfective aspect of the lexical complement relative to the imperfective baseline. In addition, we wanted to assess whether matching tense specifications in different words of a sentence can cause grammatical illusions. To this aim, we tested whether the presence of the adverb wczoraj ('yesterday') (specified for [past]) could give rise to an illusion of grammaticality for perfectives as $l$-participles (allegedly [past] marked), but not as infinitives (not having any [past] specification). The study and its results as well as a general discussion of the findings will be presented in Part II of the paper.
\end{abstract}

\section{Keywords}

processing of compound future constructions, tense and aspect mismatches, grammatical illusion, tense illusion, ERP, Polish

\section{Streszczenie}

Ten dwuczęściowy artykuł dotyczy przetwarzania dwóch rodzajów złożonych konstrukcji czasu przyszłego w języku polskim (z czasownikiem leksykalnym w formie imiesłowu i bezokolicznika). W pierwszej części przedstawiony jest projekt (design) i prognozy (hypotheses) 
badania ERP, którego celem było monitorowanie korelatów EEG dwóch rodzajów temporalnych niezgodności: i) niezgodności pod względem czasu pomiędzy czasownikiem posiłkowym czasu przyszłego a modyfikatorem czasu przeszłego wczoraj (w porównaniu z semantycznie zgodnym modyfikatorem jutro) oraz ii) niezgodności pod względem aspektu między czasownikiem posiłkowym a formą dokonaną czasownika leksykalnego (w porównaniu z wymaganą formą niedokonaną). Ponadto celem badania było sprawdzenie, czy (nie)dopasowanie pod względem kategorii czasu między określonymi słowami w zdaniu może spowodować iluzje gramatyczności poprzez określenie, czy obecność przysłówka wczoraj wywołuje złudzenie gramatyczności w przypadku dokonanych dopełnień imiesłowowych, ale nie bezokolicznikowych. Tylko pierwsze z nich są powierzchownie identyczne $\mathrm{z}$ formami czasu przeszłego, potencjalnie więc mają cechę [past]. Szczegółowy opis badania i jego wyników, a także ogólna dyskusja zostaną przedstawione w drugiej części artykułu.

\section{Słowa kluczowe}

przetwarzanie złożonych konstrukcji czasu przyszłego, niezgodności czasu i aspektu, iluzja gramatyczności, iluzja czasu (iluzja temporalna), ERP, język polski

\section{The issue}

It is a well-known fact from the literature (see, e.g., Dahl and Velupillai 2011) that languages usually possess more than one means to convey future time reference. This is also the case in Polish where future time reference can be expressed either by using a present tense form of a perfective (PFV) lexical verb (see (1)) or by using compound future constructions consisting of a future auxiliary and a lexical verb. Polish presents an especially interesting case since it has two variants of compound future constructions: one in which the future auxiliary is complemented by an infinitive (see (2)) and one in which the future auxiliary is complemented by a lexical verb in the so-called $l$-participle form (see (3)). In both cases the lexical verb complement must be in imperfective (IPFV) aspect.

(1) Janek pomaluje pokój Zosi.

Janek paint PFV.PRS.3SG $_{\text {room }}$ Zosia $_{\text {GEN }}$

'Janek will paint Zosia's room.'

(2) Janek będzie $\checkmark$ malować $/{ }^{*}$ pomalować pokój Zosi.

Janek be AUX.3SG $\sqrt{\text { paint }_{\text {IPFV.INF }} /{ }^{*} \text { paint }_{\text {PFV.INF }}}$ room Zosia ${ }_{\text {GEN }}$ 'Janek will pain/be painting Zosia's room.'

(3) Janek będzie $\checkmark$ malował $\quad /{ }^{*}$ pomalował pokój Zosi.

Janek be AUX.3SG $_{\text {paint }}{ }_{\text {IPFV.PTCP.SG.M }} /{ }^{*}$ paint $_{\text {PFV.PTCP.SG.M }}$ room Zosia ${ }_{\text {GEN }}$ 'Janek will pain/be painting Zosia's room.'

While future tense constructions in Polish has recently received an increased attention in the theoretical literature (see Błaszczak et al. 2014; Błaszczak 
2019), little is still known about the processing of these constructions. In this paper we intend to fill this gap by reporting the results of an ERP (event related potentials) study in which we examined the processing of two types of temporal mismatches in these two types of compound future constructions in Polish (see (4)): (i) aspect mismatch between the future auxiliary and the perfective aspect of the lexical complement (relative to the imperfective baseline), and (ii) tense mismatch between the future auxiliary and the past tense modifier 'yesterday' (relative to the semantically congruent 'tomorrow'). A special focus will be put on violations of type (4b) for reasons explained below.

(4) a. FUTURE AUXILIARY będzie $+{ }^{*}$ PFV $/ \sqrt{ }$ IPFV

(ASPECT MISMATCH)

b. FUTURE AUXILIARY będzie + *YESTERDAY $/ \checkmark$ TOMORROW (TENSE MISMATCH)

The first thing to notice is that here is no difference in meaning between the two variants of compound future in Polish illustrated in (2) and (3): they are in free variation (see Fisiak et al. 1978: 106). However, there is an important morphological difference between them: in contrast with the inifinitival form, the $l$-participle is specified for number and gender. What makes Polish interesting in the context of the present paper is the fact that the $l$-participle form is also a form used in the past tense constructions in Polish, as shown in (5). In contrast with compound future constructions, in past tense constructions both imperfective and perfective verbs are allowed.

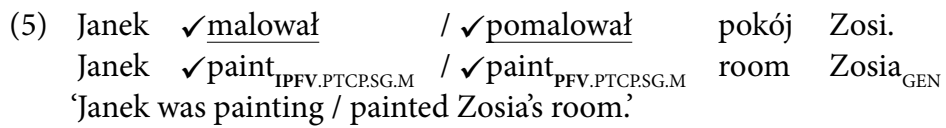

Most importantly, for third person subjects the form of the lexical verb (the underlined form in the examples below) is superficially identical in compound future with participial complements and (imperfective) past tense constructions in Polish, as shown in $(6 \mathrm{a}, \mathrm{b})$. Crucially, whereas the imperfective form of the $l$-participle is a form that can occur both in future and past constructions (see (6)), the same is not true for the perfective variant of the $l$-participle. The latter does not appear in future constructions (its use is ungrammatical there; see (7a)) but it does occur in past constructions; see (7b).

(6) imperfective $l$-participles ( $\checkmark$ future, $\checkmark$ past)

a. Janek będzie jutro $\checkmark$ malował pokój Zosi. Janek be AUX.3SG tomorrow paint ${ }_{\text {IPFV.PTCP.SG.M }}$ room Zosia ${ }_{\text {GEN }}$ 'Janek will be painting Zosia's room tomorrow.'

b. Janek wczoraj $\checkmark$ malował $\quad$ pokój Zosi. Janek yesterday paint ${ }_{\text {IPFV.PTCP.SG.M }}$ room Zosia ${ }_{\text {GEN }}$ 'Janek was painting Zosia's room yesterday'. 
(7)
perfective $l$-participles $\left({ }^{\star}\right.$ future, $\checkmark$ past)
a. Janek będzie jutro
*pomalował pokój Zosi.
Janek be AUX.3SG tomorrow paint PFV.PTCP.SG.M $_{\text {room }}$ Zosia $_{\text {GEN }}$
b. Janek wczoraj $\checkmark$ pomalował pokój Zosi.
Janek yesterday paint PFv.PTCP.SG.M $_{\text {room } \text { Zosia }_{\text {GEN }}}$ 'Janek painted Zosia’s room yesterday'

Another crucial point is the contrast between the $l$-participles, on the one hand, and the infinitival forms, on the other hand. While $l$-participles occur both in future constructions (the imperfective ones) and past constructions (both imperfective and perfective ones) (see (6)-(7)), infinitival forms are used in future constructions (the imperfective ones) but not in past constructions regardless of aspect, as shown in (8) and (9) respectively. In other words, we will not find bare uses of infinitives in past tense sentences, as in (9) (in contrast with (6b) and (7b)).

(8) future ( $\checkmark$ imperfective infinitive, ${ }^{*}$ perfective infinitive)

a. Janek będzie jutro $\checkmark$ malować pokój Zosi. Janek be AUX.3SG $_{\text {tomorrow paint }}$ IPFV.INF room Zosia ${ }_{\text {GEN }}$ 'Janek will be painting Zosia's room tomorrow.'

b. Janek będzie jutro *pomalować pokój Zosi. Janek be AUX.3SG tomorrow paint PFV.INF $_{\text {room } Z_{\text {Gesia }}}$

(9) past $\left({ }^{*}\right.$ imperfective infinitive, ${ }^{*}$ perfective infinitive)
a. Janek wczoraj ${ }^{\star}$ malować pokój Zosi.
Janek yesterday paint IPFV.INF $_{\text {room } \text { Zosia }_{\text {GEN }}}$
b. Janek wczoraj ${ }^{\star}$ pomalować pokój Zosi.

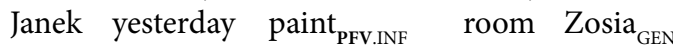

With this background in mind, we can now ask the central question of the present paper: Can matching TENSE specifications in different words of a sentence give rise to grammatical illusions and thus create opportunities for errors? In the examples provided so far, only semantically compatible temporal adverbs have been used: jutro 'tomorrow' in future sentences and wczoraj 'yesterday' in past tense sentences. The intriguing question is what will happen when in future sentences (with a future auxiliary), instead of 'tomorrow', a semantically incongruent temporal modifier 'yesterday' is used. Thus, the scenario (comparison) we are interested in would be the following:

(10) a. future auxiliary + tomorrow + lexical verb + object

vs.

b. future auxiliary + yesterday + lexical verb + object 
Of course, the use of wczoraj 'yesterday' violates the selectional restriction of the future auxiliary, so such sentences are ungrammatical and judged as such by native speakers. The important question is, however, whether the presence of 'yesterday' will affect the processing of the lexical verb and the following element in the sentence in any other significant way in addition to the violation caused by the mismatch between the future auxiliary and the past tense modifier. Will the comprehender be misled by the presence of the past tense modifier and at least fleetingly consider it for the purpose of interpretation? Importantly, the presence of 'yesterday' should not have any misleading effect in the case of infinitival complements. This is because, as has been pointed out above (recall (9)), infinitives (unless they are a complement of some modal verb) are not used in past sentences and they are certainly not specified for past tense features, as indicated in (11)-(12) (asterisks indicate the source of ungrammaticality).

(11a) 'tomorrow_imperfective_infinitive'

$\begin{array}{llllll}\text { Janek } & \text { będzie } & \text { jutro } & \text { malować } & \text { pokój } & \text { Zosi. } \\ \text { Janek } & \text { will } & \text { tomorrow } & \text { paint }_{\text {IPFV.INF }} & \text { room } & \text { (of) Zosia } \\ & {[\text { FUTURE }]} & {[\text { FUTURE }]} & {[} & & \end{array}$

(11b) 'yesterday_imperfective_infinitive'

$\begin{array}{llllll}\text { Janek } & \text { będzie } & { }^{*} \text { wczoraj } & \text { malować } & \text { pokój } & \begin{array}{l}\text { Zosi. } \\ \text { Janek }\end{array} \\ \text { will } & \text { yesterday } & \text { paint }_{\text {IPFV.INF }} & \text { room } & \text { (of) Zosia } \\ & {[\text { FUTURE] }} & {[\text { PAST }]} & {[} & & \end{array}$

(12a) 'tomorrow_perfective_infinitive'

$\begin{array}{lllll}\text { Janek } & \text { będzie } & \text { jutro } & { }^{*} \text { pomalować pokój } & \text { Zosi. } \\ \text { Janek } & \text { will } & \text { tomorrow } & \text { paint }_{\text {PFv.INF }} \text { room } & \text { (of) Zosia } \\ & \text { [FUTURE] } & \text { [FUTURE }] & {[\quad[\quad]} & \end{array}$

(12b) 'yesterday_perfective_infinitive'

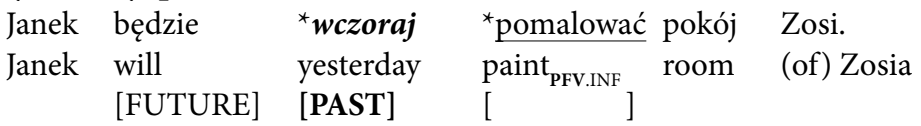

The situation might be different in the case of participial complements since as discussed above (recall (6) and (7)) - these are the forms which are also used in past tense constructions; hence, they could potentially be associated with a [past] feature (either intrinsically or this feature could be activated (primed) on a participle in the immediate vicinity of a past tense modifier 'yesterday' if necessary, i.e., when there is an error signal at that position). In other words, given that the combination of a past tense modifier 'yesterday' and an $l$-participle as such is a licit piece of structure and it has an acceptable interpretation on its own (as a fragment) (recall (6b) and (7b)), one might potentially expect it to be suspectible to a grammatical illusion, as indicated in (13)-(14) (again, the asterisks indicate the source of ungrammaticality in 
each case). ${ }^{1}$ This illusory licensing effect might be stronger in the case of perfective participles, as in (14b), than in the case of imperfective participles, as in (13b). This is because an imperfective participle, but not a perfective one, by itself is compatible with (is licensed by) the future auxiliary. By contrast, a perfective participle is not licensed by the future auxiliary, but it is very well compatible with a past tense modifier, which might mislead the comprehenders even stronger.

(13a) 'tomorrow_imperfective_participle'

$\begin{array}{llllll}\text { Janek } & \text { będzie } & \text { jutro } & \text { malował } & \text { pokój } & \text { Zosi. } \\ \text { Janek } & \text { will } & \text { tomorrow } & \text { paint }_{\text {IPFV.PTCP.SG.M }} & \text { room } & \text { (of) Zosia } \\ & {[\text { FUTURE] }} & \text { [FUTURE] } & {[\quad[\quad]} & & \end{array}$

(13b) 'yesterday_imperfective_participle'

$\begin{array}{llllll}\text { Janek } & \text { będzie } & { }^{*} \text { wczoraj } & \text { malował } & \text { pokój } & \begin{array}{l}\text { Zosi. } \\ \text { Janek }\end{array} \\ \text { will } & \text { yesterday } & \text { paint } & \text { rPFv.PTCP.SG.M } & \text { room } & \text { (of) Zosia } \\ & \text { [FUTURE] } & \text { [PAST] } & \text { [??PAST] } & & \end{array}$

(14a) 'tomorrow_perfective_participle'

$\begin{array}{llllll}\text { Janek } & \text { będzie } & \text { jutro } & { }^{*} \text { pomalował } & \text { pokój } & \begin{array}{l}\text { Zosi. } \\ \text { Janek }\end{array} \\ \text { will } & \text { tomorrow } & \text { paint }_{\text {PFv.PTCP.SG.M }} & \text { room } & \text { (of) Zosia } \\ & \text { [FUTURE] } & \text { [FUTURE] } & {\left[\quad\left[{ }^{2}\right]\right.} & & \end{array}$

(14b) 'yesterday_perfective_participle'

$\begin{array}{llllll}\text { Janek } & \text { będzie } & { }^{*} \text { wczoraj } & { }^{*} \text { pomalował } & \text { pokój } & \begin{array}{l}\text { Zosi. } \\ \text { Janek }\end{array} \\ \text { will } & \text { yesterday } & \text { paint }_{\text {PFv.PTCP.SG.M }} & \text { room } & \text { (of) Zosia } \\ & {[\text { FUTURE] }} & \text { [PAST] } & \text { [?PAST] } & & \end{array}$

Putting all these observations together, if matching TENSE specifications in different words of a sentence can cause grammatical illusions, then we may expect to find significant differences in the online processing of the two variants of compound future constructions in Polish. More precisely, two such differences are potentially expected. For one thing, illusory licensing effects may arise with participial complements but not the infinitival ones, and secondly, the interference from the mismatching adverbial 'yesterday' may be stronger for perfective participles than imperfective ones.

Table 1 provides an overview over the present ERP study (see Part II for details). In order to be able to formulate specific predictions as to expected ERP outcomes, we will first provide the necessary background in section 2 . We will

\footnotetext{
${ }^{1}$ The corpus search (the full National Corpus of Polish (NKJP), 1800M segments, Przepiórkowski et al. 2012) has not revealed relevant examples which could indicate a tense illusion effect. Only one potential candidate example with 'yesterday' and future auxiliary będzie + l-participle (wczoraj będzie miat 'yesterday (he) will have ${ }_{\text {PTCP.SG }}$ ') has been found (see [IJPPAN_PolPr_GKb00202]). However, from the previous context it is not clear what the intended temporal reference is: whether it is past tense (in which case, the sentence should be wczoraj miat 'yesterday (he) had') or whether it is rather future time (in which case the correct form would be będzie miat '(he) will have').
} 
start with a brief summary of the relevant findings from previous ERP studies on tense/aspect violations (section 2.1), followed by a concise overview of real-time sentence processing and linguistic illusions (section 2.2), as well as relevant observations concerning the processing of ungrammatical sentences containing two anomalies (section 2.3), since such sentences are of primary interest in the context of the present research question [recall ex. (12b) and (14b)]. On this basis, we will then formulate our research hypotheses in section 3. The study and its results will be presented in Part II of this paper.

Table 1. Experimental design and sample set of stimuli sentences ${ }^{2}$ (asterisks indicate the source of ungrammaticality)

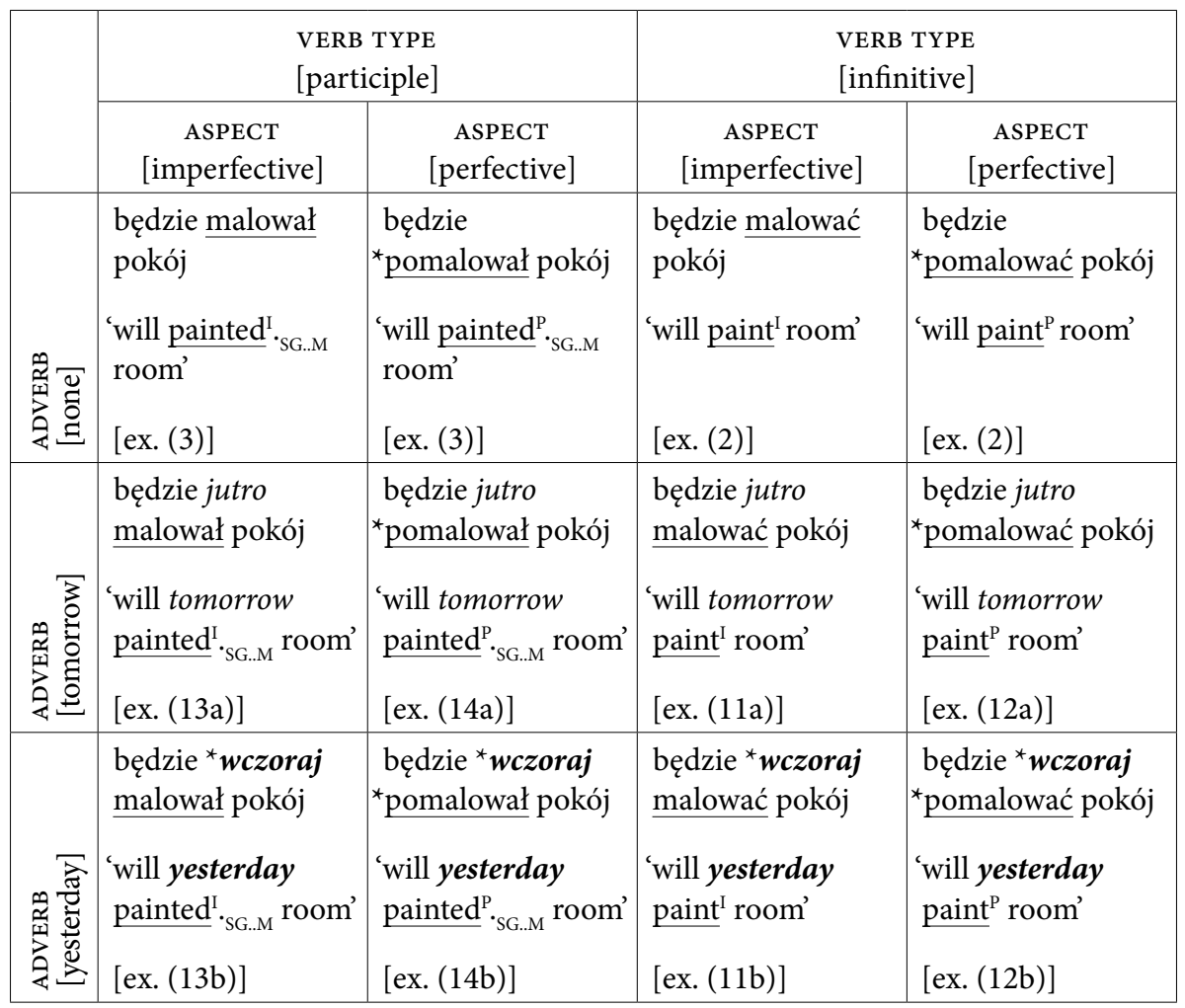

\footnotetext{
${ }^{2}$ In Table 1 only the relevant fragments of stimuli sentences are presented in the interest of clarity. Also the English glosses are simplified: the forms 'painted' and 'paint' are used as glosses for $l$-participles and infinitives respectively. Aspect values are indicated by the superscript I and $\mathrm{P}$ (for imperfective and perfective respectively).
} 


\section{Relevant background}

\subsection{Previous ERP research on tense/aspect violations}

The previous ERP studies on tense/aspect violations basically include two types of anomalies (see Dillon et al. 2012). The first type concerns the morphosyntax of the auxiliary-verb sequences (specific morphosyntactic requirements), as schematized in (15a). The second type of error is caused by the mismatch between a temporal adverbial, to be more precise, the temporal frame specified by the adverbial modifier in which the main eventuality has to be located, and the (tense/aspect) form of the verb, as indicated in (15b). Importantly, none of the studies discussed below examined the question of potential tense-related illusions of grammaticality. As will become immediately clear, the stimuli used in these studies did not allow to ask such a question either as there was no element involved which could cause interference and mislead the comprehender in the first place.

(15) a. * Auxiliary $>$ Verb (in a wrong form)

b. * Temporal Adverbial > Verb (in a wrong tense/aspect form)

Concerning the first type of anomaly, two ERP studies are of interest. Osterhout and Nicol (1999) investigated, among other things, structures with a modal verb which was incorretly followed by a present participle (-ing) form of the verb, as in The new fighter planes can ${ }^{\star}$ flying faster than anyone expected (ibid., p. 289). In Allen et al.s (2003) study sentences with the auxiliary will followed by the past tense form of a lexical verb, as in The man will ${ }^{*}$ worked $/{ }^{*}$ stood on the platform (ibid., p. 410), were examined. In both studies, the ERPs elicited by the incorrect verb forms, as compared with the correct ones, were significantly more positive in the late time window (500-800 ms epoch in Osterhout and Nicol's 1999 study and 500-900 ms epoch in Allen et al.'s 2003 study), and these effects were maximal in posterior sites, which is consistent with the distribution of the P600. In an earlier time window, 300-500 ms post onset of the verb, the effects were negligible.

As far as tense violations of type (15b) are concerned, in various studies two major effects, an early negativity and a late positivity, have been reported. The reported positivities showed a timing at around $600-700 \mathrm{~ms}$ and a posterior scalp distribution, which is characteristic of a P600. In contrast, the observed negativities in the responses to the anomaly caused by the mismatch between the temporal modifier and the (tense/aspect) form of the verb revealed differences in the topography and temporal profile across studies, which might be due to the specifics of the linguistic stimuli used in the respective studies. For example, Steinhauer and Ullman (2002) and Newman et al. (2007) investigated English sentenses in which the adverb yesterday was erroneously followed 
by a stem (unmarked) form of (regular and irregular) verbs instead of their correct past tense forms; cf. Yesterday, I ${ }^{*}$ sail Diane's boat to Boston / Yesterday, we *eat Peter's cake in the kitchen (Steinhauer and Ullman 2002: 63); Yesterday $I{ }^{\star}$ frown at Billy / Yesterday I ${ }^{\star}$ grind up coffee (Newman et al. 2007: 438). The first study reports centro-parietal (N400-like) negativities in the 300-400 ms time window (for irregular verbs) and left-anterior negativity (LAN) in the 400-500 ms time window (for regular and irregular verbs). Newman and colleagues found an enhanced left-anterior negativity for regular verbs in the $300-500 \mathrm{~ms}$ time window. Notably, neither study report differences in the late positivities elicited by erroneously used regular and irregular verbs.

Unlike in the two studies mentioned above, in other studies, for example, by Baggio (2004, 2008), Zhang and Zhang (2008), Dillon et al. (2012), the verb form mismatching the temporal specification of the adverbial modifier was explicitely morphologically marked. In the study reported in Baggio (2008) (see also Baggio 2004), Dutch sentences with a past temporal modifier followed by a present tense verb as in Afgelopen zondag ${ }^{*}$ lakt Vincent de kozijnen van zijn landhuis 'Last Sunday *paints Vincent the window-frames of his country-house' (ibid., p. 43) were investigated. Tense violations elicited a negativity over left-anterior scalp sites with a latency of 200-400 ms after the verb onset which was followed by a positivity over right-posterior sites at about $700 \mathrm{~ms}$. Also Dillon et al. (2012) found a similar biphasic, negative-positive, response to tense violations in Hindi, where the violation consisted in a mismatch between a past temporal modifier and a future tense nonperfective form of the verb (correctly, the verb should be in past perfective form). However, unlike in Baggio's study, the negativity reported by Dillon and colleagues for the 200 $400 \mathrm{~ms}$ time window showed a posterior rather than anterior scalp distribution. A negativity with a similar latency $(200-400 \mathrm{~ms})$ and distribution (posterior and left central) followed by a P600 was also found by Zhang and Zhang (2008) in response to aspectual mismatches in Chinese Mandarin, for example, in sentences in which the progressive (imperfective) adverbial zhengzai 'ongoing' was followed by the incompatible perfective marker le (ibid., p. 1040).

Before concluding this subsection, one remark is in order. In the studies reported above, the temporal adverbial always preceeded the errorenously used verb form. Baggio's (2004) study on tense violations in Dutch is a remarkable exception in this respect as he also examined sentences in which a verb in the present tense form was followed by a past tense modifier, as in Julian wint ${ }^{*}$ afgelopen lente een literatuur prijs in Frankrijk 'Julian wins *last spring a literature prize in France' (ibid., p. 11). Similarly to the ERP effects reported in the other studies mentioned above, in incorrect sentences, as compared with the correct ones, ERPs to the critical segment (temporal adverbial) were more negative over left frontal and fronto-central sites in the 300-500 ms time window and more positive over right temporo-parietal sites in a later time window 
(with a peak around $800 \mathrm{~ms}$ ). However, these effects failed to reach statistical significance (ibid., pp. 14, 18).

To sum up the discussion so far, tense/aspect violations elicited late posterior positivities (a P600) on the critical segment (be it an erroneous verb form or an incompatible adverbial) consistently across various studies. Additionally, in the earlier time windows (200-400 ms, 300-500 ms) locked to the onset of a critical segment, negativities have been reported.

\subsection{Real-time sentence processing and linguistic illusions}

As we have seen in the preceding section, the human parser is constrained by grammatical constraints at very early stages of analysis and it is able to detect mismatching feature specifications as early as at 300-500 ms after the onset of a critical stimulus (for further discussion, see Kaan 2007 and the references cited there). There is also evidence that the parser respects sytanctic constraints, for example, it does not attempt to associate fillers with syntactically inaccessible positions, located in the so-called syntactic 'islands'. The parser does not consider ilicit antecedents for reflexive pronouns either, thus obeying Principle A of the Binding Theory (see Phillips et al. 2011). The initial impression of a perfectly working parser that can implement even complex grammatical constraints with high accuracy is not correct, though, as there is plenty of experimental evidence that the parser makes errors and is less accurate in the implementation of some other, in fact often simple constraints (Lewis and Phillips 2015; Phillips et al. 2011). For example, the parser seems to be misled by the presence of a potential but structurally inaccessible licensor for a negative polarity item (NPI) (here: ever) in cases such as The restaurants (that no local newspapers have recommended in their dining reviews] have ever gone out of business (Xiang et al. 2009: 44). The results of speeded grammaticality judgements (see Drenhaus et al. 2005 for German) show that the presence of a negative licensor in a structurally inaccessible (non-c-commanding) position increases the acceptance rates, that is, participants incorrectly more often accept such sentences relative to sentences with no licensor at all (cf. ${ }^{*}$ Most restaurants [that the local newspapers have recommended in their dining reviews] have ever gone out of business), which suggests that they fleetingly treat such sentences as appropriately licensed (Lewis and Phillips 2015: 37). Xiang et al. (2009: 47-48) in their ERP experiment on NPI processing in English found a reduction of the $\mathrm{P} 600$ in ungrammatical sentences with a potential but structurally inaccessible (non-c-commanding) licensor, as compared to ungrammatical sentences with no licensor at all, which the authors take to indicate "that the intrusive licensor in some way disrupts the earliest stages of grammaticality detection for NPIs" (ibid., p. 51).

Illusory licensing effects have been found not only for NPIs. Other prominent examples demonstrating the susceptibility of comprehenders to 
grammatical illusions include case (see, e.g., Bader and Meng 1999; Bader et al. 2000) and agreement in gender (see, e.g., Slioussar and Malko 2016) and number. With respect to the latter, it has been shown in the literature (see Bock and Miller 1991; Clifton et al. 1999; Pearlmutter et al. 1999) that (both in production and comprehension) speakers often fail to notice in sentences like (16a) that the number marking of the verb is incorrect (it should be singular, instead of plural, to match the singular form of the subject; cf. (16b)) when some nominal phrase other than the controller of agreement (here: the cabinets) has the matching (here: plural) feature.

(16) a. ${ }^{*}$ The key[SG] to the cabinets[PL] are[PL] missing.

vs. b. $\checkmark$ The key[SG] to the cabinets[PL] is[SG] missing.

In comprehension, such an illusion of grammaticality manisfests, e.g., in higher error rates and prolonged response times for correct judgements in acceptability rating studies (Clifton et al. 1999; see Häussler 2012 for an overview). Importanly, against the initial impression in (16), the linear proximity between the verb and the "intervening" NP is not a prerequisite for grammatical illusions, as similar effects have also been observed in relative clause configurations, e.g., The drivers[PL] who the runner[SG] wave[PL] to each morning honk back cheerfully, in which the distractor (here: the drivers) does not intervene between the verb and its subject and despite that, comprehenders are misled by its presence (Wagers et al. 2009: 209).

Another relevant observation is that whereas the incorrect agreement in (16a) due to the interference from another NP frequently leads to an illusion of grammaticality, the opposite is seldom the case (Lewis and Phillips 2015: 36). That is, the correct agreement in (16b) normally does not lead to an illusion of ungrammaticality due to interference from another NP (see Wagers et al. 2009). In other words, there is an asymmetry: illusion effects seem to be restricted to or at least be stronger in ungrammatical sentences (but see Perlmutter et al. 1999; Pearlmutter 2000, and Häussler 2012: 146-148, 287-289 for a general discussion). It seems that the mismatch between the verb and subject number (an error signal) may trigger a reanalysis mechanism, which "can check back to see if an error was made" (Wagers et al. 2009: 233). ${ }^{3}$ Notably, this mechanism is not called upon in cases when the verb matches the predicted number feature as in the latter case there is no mismatch that would need to be fixed. Wagers et al. (2009) propose that the mechanism in question makes use of cue-based retrieval: all objects in memory are simultaneously probed for their match to particular featural

\footnotetext{
${ }^{3}$ Wagers et al. (2009) take the observed asymmetry (lack of ungrammatical illusions) as an argument speaking against accounts attributing agreement errors to faulty representation of subject number. Häussler (2012) proposes a hybrid model which assumes that agreement errors can happen both during the structure assembly phase and during the checking phase.
} 
cues (Lewis and Phillips 2015: 36). It seems that during this reanalysis process a "wrong" element can be mistakenly retrieved if it matches the retrieval cues in some relevant way (see Phillips et al. 2011; Wagers et al. 2009). ${ }^{4}$

To sum up, the discussion so far has shown that the parser can accurately apply many grammatical constraints but in some cases it reveals a suprising fallibility. NEGATION (NPI licensing), CASE, NUMBER, GENDER are suspectible to grammatical illusions. ${ }^{5}$ The behavioral manifestations of grammatical illusions are increased acceptability rates for incorrect sentences under time pressure (higher error rates and prolonged response times for correct judgements). Electrophysiologically, grammatical illusions, which could be understood as "sucessful interference", can manifest in a reduced (or absent) P600. To the best of our knowledge, there is no work showing that matching TENSE specifications in different words of a sentence can cause grammatical illusions, similar to what has been described for other grammatical illusion phenomena.

\subsection{Processing of ungrammatical sentences with two anomalies}

As pointed out in section 1, the crucial sentences in the context of the central research question of the present paper are ungrammatical sentences with compound futures containing two anomalies: (i) the mismatching past tense modifier 'yesterday' and (ii) a mismatching perfective $l$-participle (see (17), repeated from (14b) for convenience).

(17) * Janek będzie [FUTURE]

\section{wczoraj pomalowat pokój Zosi.}

yesterday paint ${ }_{\text {PFV.PTCP.SG.M }}$ room (of) Zosia

In a comparable ERP study by Molinaro et al. (2008) the processing of ungrammatical sentences that contain two agreement anomalies, an early and a late anomaly, as shown in (18a,b), is investigated.

(18) a. ${ }^{*}$ The famous dancer $[\mathrm{SG}]$ were $[\mathbf{P L}]$ nervously preparing themselves $[\mathbf{P L}]$ to face the crowd.

b. ${ }^{*}$ The famous dancer[SG] were[PL] nervously preparing herself[SG] to face the crowd.

vs. c. $\checkmark$ The famous dancer[SG] was[SG] nervously preparing herself[SG] to face the crowd.

\footnotetext{
${ }^{4}$ In the literature several competing accounts of how linguistic illusions come about have been proposed, including the relative role of cue-based retrieval, overapplication of alternative processing pathways, or feature percolation, depending on the type of illusion (Häussler 2012; Parker and Phillips 2016; Vasishth et al. 2008; Xiang et al. 2009).

${ }^{5}$ Another well-known case of a very powerful illusion effect is the so-called comparative illusion; cf. More people have been to Russia than I have (Townsend and Bever 2001; Wellwood et al. 2018).
} 
The most important observation is that the processing of the later anomaly (here: at the pronoun herself or themselves) can be affected by the processing of the early anomaly (here at were). Molinaro and colleagues found that in cases in which the form of the reflexive pronoun did not match that of the verb (as in (18b)), pronouns elicited a distributed positivity resembling the P600 effect. However, this effect was not found when the form of the reflexive pronoun matched that of the verb (as in (18a)). Molinaro at al. (2008: 973) suggest that this could mean that even if the reflexive pronoun should agree in number both with the finite verb and the subject (as in (18c)), in cases in which the subject disagrees with the verb (as in (18a) and (18b)), the number agreement of the reflexive pronoun is checked only with respect to the more recent of the two number-marked constituents with which it should agree, namely the finite verb. In other words, "the ungrammatical sentence fragment at the verb is left in stand-by, and the system goes on checking the agreement between verb and pronoun, treated as coherent parts of the verb phrase" (ibid., p. 973). ${ }^{6}$ Under this assumption, the processor detects (and tries to repair) agreement violation (mismatch in number between the form of the reflexive pronoun and the form of the finite verb) only in the case of (18b) but not in the case of (18a), which would explain the lack of the P600 in the latter case. In the following text, this explanation will be referred to as the recency account.

Another possible explanation, as pointed out by Molinaro and colleagues (ibid., p. 972), could be that the first (early) anomaly is resolved in favour of the element at which the violation is detected (here: were). In other words, "after failing to find number agreement between the subject and the verb, the parser modifies the number of the previous fragment representation so that it agrees with the verb number" (Molinaro et al. 2008: 972) (this can be viewed as a kind of coercion). ${ }^{7}$ Accordingly, after the first anomaly (incongruency in number) has been resolved, the number of the following reflexive pronoun would then have to agree with the number of the verb, as in (18a). A disagreeing reflexive pronoun, as in (18b), in contrast would evoke a P600. ${ }^{8}$ Henceforth, this explaination will be referred to as the coercion account.

Another important observation in the context of our study is that ERPs to final words in ungrammatical sentences have been reported to be more

${ }^{6}$ As Molinaro et al. (2008: 973) point out, "[i]n this case there is no need to presuppose an ungrammaticality resolution."

${ }^{7}$ Note that the two explanations proposed by Molinaro et al. (2008), a "coercion" and a "recency" account, resemble the hybrid account of agreement errors put forward by Häussler (2012); see section 2.2, footnote 3 .

${ }^{8}$ In this context, the following remark by Baggio (2004) is of interest. He asked the participants of his study (see section 2.1) in debriefing interviews what they found anomalous with the sentences they read. The answer was unanimously that is some cases the tense of the verb did not match the temporal adverbial. It seems that the participants' intuition was that "verb tense had to match with the adverb rather than the inverse" (ibid, p. 22). 
negative-going than ERPs to final words in grammatical sentences, even if the word/constituent which causes the anomaly does not occupy the sentencefinal position (see, e.g., Osterhout and Holcomb 1992). This effect has been shown to be independent of the type of anomaly involved (see, e.g., Osterhout and Nicol 1993; Hagoort 2003). Sentence-final negativity is also reported by Baggio (2008) in his study on tense violations in Dutch. The negativity, though superficially resembling the N400, was more sustained (400-700 ms) and had a later maximum (ibid., p. 45). Baggio suggests that this negativity could be seen as a reflection of the parser's attempts to compute a meaningful sentence. Similarly, Bos et al. (2013: 296) take such sentence-final negativities "to reflect the extent to which processing difficulties can or cannot be resolved." What is particularly interesting is that the amplitude of such long-lasting negativities to words in sentence-final position is larger in ungrammatical sentences containing two anomalies than in sentences with only one anomaly (Osterhout and Nicol 1993; Hagoort 2003). It seems that the observed sentence-final negativity may be regarded as a reflection of processing problems at earlier positions in the sentence, or in Hagoort's (2003) words, it is "presumambly related to the consequences of the earlier violations for the overall integration of the sentential information into one coherent message" (p. 895). In a similar vein, Osterhout and Holcomb (1992: 799) suggest that "the negative-going wave might be an electrophysiological response to the perceived ungrammaticality" [original emphasis]. Note in this connection that the amplitude/size of the negativity found in ERP responses to sentence-final words in ungrammatical sentences seem to closely correlate with the acceptability judgements (behavioral data) obtained during an ERP experiment. As reported by Hagoort (2003), in his ERP study (see above) sentences with a double anomaly were rated as unacceptable in $99 \%$ of the cases. The acceptablity rates in the case of sentences with only one anomaly were slightly higher (sentences with a syntactic violation were rated as unacceptable in $97 \%$ of the cases and those with a semantic violation in $90 \%$ of the cases) (ibid., p. 887).

With this background provided, we can now formulate our predictions.

\section{Predictions and relevant comparisons}

\subsection{Electrophysiological data - expected outcomes}

As stated in section 1, the present study has two aims: firstly, to monitor the EEG correlates of mismatches between future tense auxiliary and perfective aspect relative to the imperfective baseline as well as mismatches between the future auxiliary and the past tense modifier 'yesterday' relative to the 'tomorrow' baseline, and secondly, to assess whether the presence of the adverb 
'yesterday' (specified for [+past]) could give rise to an illusion of grammaticality for perfectives as $l$-participles, but not as infinitives.

To assess the mismatch between the future auxiliary and the past tense modifier 'yesterday' a comparison between 'yesterday' and 'tomorrow' conditions at the ADVERB position is necessary. Since all conditions containing adverbs are identical at this position (the different verb types and aspects are not available yet) (see Table 1), the only relevant question is whether there is a mismatch between the future auxiliary and 'yesterday', but not 'tomorrow'. Following the previous literature, the mismatching adverb 'yesterday' is expected to elicit elicit a negativity (LAN) followed by a posterior positivity (P600).

To assess the mismatch between the future auxiliary and the perfective aspect, a $2 \times 2$ comparison of $A S P E C T^{*} V E R B$ applied to all 'no adverb' conditions at the VERB position is required. The prediction is that there will be a mismatch between the future auxiliary and perfective aspect, independently of verb type. In other words, we expect to find a main effect of ASPECT, but no interaction with VERB. More specifically, following the previous literature, the mismatching perfective aspect is expected to elicit a P600 (possibly preceded by an earlier negativity), both on participles and infinitives.

To assess whether the presence of the past tense modifier 'yesterday' could give rise to an illusion of grammaticality for perfective $l$-participles, but not perfective infinitives, we also need to perform a $2 \times 2$ comparison of ASPECT ${ }^{\star}$ VERB. This comparison needs to be applied to all 'yesterday' conditions at the VERB and OBJECT positions. Below we formulate our predictions with regard to these two positions following the recency and the coercion account, introduced in section 2.3 , respectively.

\section{VERB position}

\section{The recency account}

Under the recency account of Molinaro et al. (2008), in sentences containing two anomalies: an early and a late anomaly, the first anomaly might be "left in stand-by" (it may remain unresolved; see section 2.3, fn. 6) and the second incongruency may be checked only with respect to the word at which the first anomaly was detected. Finding a matching feature, the incongruency can be resolved/repaired, giving rise to a grammatical illusion. Following this account, in sentences containing the past tense modifier 'yesterday' the mismatch between between the future auxiliary and 'yesterday' could be "left in stand-by" provided that there is a later anomaly (an error signal at the VERB position) necessary to trigger a repair mechanism/a reanalysis process during which the later anomaly is checked only with respect to the first mismatch. 
This would be the case with perfectives but not imperfectives since the latter match the selectional restrictions of the future auxiliary, so no repair mechanism will be necessary/called upon at the VERB position in their case. However, for the mismatch between the future auxiliary and the perfective aspect to be resolved in favour of the element at which the first mismatch was detected (i.e., the past tense modifier 'yesterday'), the perfective complement must have a matching [past] feature. Given that only the participle but not the inifnitive can have a [past] specification, we might expect interference from 'yesterday' only in the former case, which would manifest in a weaker or absent P600 (grammatical illusion). Thus our first prediction under the recency account is that infinitives should have an enhanced P600 relative to participles with perfectives, but not with imperfectives.

Note furthermore that, assuming that there will be grammatical illusions in sentences with the mismatching past tense adverb 'yesterday' and perfective participles, they should be perceived as at least as grammatical/acceptable as ungrammatical sentences with the mismatching past tense adverb 'yesterday' and imperfective participles. In the latter case there is only one violation, namely that at the adverb position: the mismatch between the future auxiliary and 'yesterday' (the imperfective complement, being congruent with the future auxiliary, will not trigger a repair mechanism (see above)). In the former case - as explained above - the first mismatch, i.e., that between the future auxiliary and 'yesterday', may remain unresolved, and the second mismatch (due to the erroneously used perfective aspect) may be repaired by finding a matching feature [past] on the participle and the temporal modifier.

The situation should be different in the case of sentences with the mismatching past tense adverb 'yesterday' and perfective and imperfective infinitival complements. The former (perfective infinitives) cannot be "repaired" in the manner described for ungrammatical sentences with 'yesterday' and perfective participles, since infinitives do not have the [past] feature. As a consequence, this anomaly (the aspect violation) will remain unresolved, in addition to the unresolved first anomaly (the incongruency between the future auxiliary and the past tense modifier 'yesterday'). Hence our second prediction under the recency account is that perfectives should lead to an enhanced P600 relative to imperfectives with infinitives, but not with participles.

\section{The coercion account}

Our predictions would be partly different if we followed an alternative explanation of how sentences containing two anomalies, an early and a late one, are processed, namely the coercion account suggested by Molinaro et al. (2008). On this alternative account the assumption would be that the mismatch between the future auxiliary and the past tense modifier 'yesterday' could be resolved in favor of 'yesterday' (see section 2.3., in particular fn. 8). Note that 
if the reference time could simply be coerced to be past, the following verb would be checked with respect to that property. Both perfective and imperfective participles would be compatible with that specification (as they have or can be associated with the [past] feature), which would give rise to a grammatical illusion. In contrast, neither perfective nor imperfective infinitives would be compatible with this coerced past specification (as they lack the [past] feature) (no grammatical illusion). Hence under the coercion account our first prediction is that infinitives should have an enhanced $\mathrm{P} 600$ relative to participles, both for perfectives and imperfectives, and the second prediction is that perfectives should not have an enhanced 600 relative to imperfectives, neither for infinitives nor for participles.

\section{OBJECT position}

\section{The recency account}

Following the recency account, if ungrammatical sentences containing the mismatching past tense adverb 'yesterday' and perfective participles could be repaired in the manner described above thanks to the matching tense specifications [past] on 'yesterday' and 'participle', then we might expect that the following object would be integrated into the just "repaired" fragment resulting in a coherent structure: wczoraj pomalowat pokój - 'yesterday (he) painted.PVF a room. Such sentences might thus be erroneously perceived as (relatively) grammatical (coherent structures) (grammatical illusion). By contrast, in the case of ungrammatical sentences containing the mismatching past tense adverb 'yesterday' and perfective infinitives, this incongruency cannot be resolved/repaired due to the lack of the [past] specification on the infinitive. The following object might thus be expected not to be easily integratable into this flawed fragment of structure (wczoraj pomalować pokój - 'yesterday (to) paint.PVF a room"): the parser will "struggle" with it and the sentence will be perceived as ungrammatical (no grammatical illusion).

As far imperfective complements are concerned, as explained above, since they match the selectional restrictions of the future auxiliary, no signal error is expected at the verb position which would necessitate a repair mechanism, which in turn could be affected by the mismatching adverbial 'yesterday'. The following object should thus be equally easily or equally arduously integratable into the just-processed fragment of structure in the case of ungrammatical sentences with the mismatching past tense adverb 'yesterday' and either imperfective infinitives or imperfective participles. Hence, under the recency account our first prediction is that at the OBJECT position infinitives should have an enhanced negativity compared to participles for perfectives, but not imperfectives. 
Note furthermore that - as explained above - on the assumption that there will be grammatical illusions in sentences with the mismatching past tense adverb 'yesterday' and perfective participles, they should be perceived as at least as grammatical/acceptable as ungrammatical sentences with the mismatching past tense adverb 'yesterday' and imperfective participles. By contrast, ungrammatical sentences with the mismatching past tense adverb 'yesterday' and perfective infinitives, because of two unresolved anomalies, should be perceived as more ungrammatical/unacceptable than ungrammatical sentences with the mismatching past tense adverb 'yesterday' and imperfective infinitives, which only have one anomaly. Hence our second prediction under the recency account is that at the OBJECT positition perfectives should have a stronger negativity than imperfectives for infinitives, but not for participles.

\section{The coercion account}

On the alternative account, in terms of coercion our predictions partly differ from those formulated above. More precisely, under the assumption that the reference time could be coerced to be past, only participles (in either aspect), which potentially have or can be associated with the [past] feature, but not infinitives (irrespectively of aspect), which do not have any [past] feature, would be compatible with that specification. The following object would thus be expected to be more easily integratable into the just-processed fragment both in the case of perfective and imperfective participles, which could lead to seemingly coherent (acceptable) structures (cf. wczoraj pomalował pokój'yesterday (he) painted a room'; wczoraj malowat pokój - 'yesterday (he) was painting a room') (grammatical illusion), than in the case of the of perfective and imperfective infinitives, where no comparable coherent (or potentially acceptable) structures can be established (cf. wczoraj pomalować pokój - 'yesterday (to) paint.PVF a room'; wczoraj malować pokój - 'yesterday (to) paint.IPVF a room') (no grammatical illusion). Hence under the coercion account our first prediction is that at the OBJECT position infinitives should have a stronger negativity than participles for perfectives and imperfectives, and the second prediction is that there should be no difference between both aspects, neither for participles nor for infinitives.

\subsection{Behavioral data - expected outcomes}

Recall that the behavioral manifestations of grammatical illusions are increased acceptability rates for incorrect sentences (higher error rates and prolonged response times for correct judgements). The only relevant comparisons are those involving 'yesterday' conditions. 


\section{The recency account}

Following the explanations provided above, grammatical illusions would be expected in ungrammatical sentences with the past tense modifier 'yesterday' and perfective participles but not in those with perfective infinitives. Accordingly, in 'yesterday' conditions, we should expect longer response times and higher error rates (increase in acceptability due to grammatical illusion) for perfective participles relative to perfective infinitives (no grammatical illusion).

As for ungrammatical sentences with the past tense modifier 'yesterday' and imperfective complements, no grammatical illusions are expected, neither for participles nor for infinitives. This follows from the fact that, since imperfective complements match the selectional restrictions of the future auxiliary, no signal error is expected at the verb position which would necessitate a repair mechanism, which in turn could be affected by the past tense adverb 'yesterday'. Accordingly, in the grammaticality judgment task in 'yesterday' conditions there should be no considerable differences in response times and error rates between imperfective participles and imperfective infinitives. Moreover, since - as explained above - doubly anomalous ungrammatical sentences with perfective participles might be expected to be perceived (due to a potential grammatical illusion) as at least as grammatical as the anomalous sentences with imperfective participles (only one anomaly, no grammatical illusion), longer response times and higher error rates should be expected for perfective participles relative to imperfective ones. As no grammatical illusions are expected to arise in ungrammatical sentences with the past tense modifier 'yesterday' and infinitives, in 'yesterday' conditions both perfective and imperfective infinitives should be correctly judged as ungrammatical and, thus, as such they should potentially lead to comparable response times and accuracies.

\section{The coercion account}

As was explained in the preceding text, under this account grammatical illusions are expected to arise in ungrammatical sentences with the past tense modifier 'yesterday' and participles, both perfective and imperfective ones. By contrast, no grammatical illusions are expected for ungrammatical sentences with 'yesterday' and infinitives, neither perfective nor imperfective ones. Accordingly, in the grammaticality judgment task in 'yesterday' conditions we should expect longer response times and higher error rates for participles than infinitives, both with perfectives and imperfectives. However, response times and error rates should not differ between both aspects, neither in the participle nor in the infinitive conditions.

The paper will be continued in SPL 15(1), 2020. The second part will present the details of the conducted ERP study and discuss its results as well as offer first tentative explanations of the reported findings, discussing different possible underlying reasons, and also pointing out directions for future research. 


\section{Acknowledgements}

This work was supported by the "Foundation for Polish Science (FNP)" (Grant FOCUS no. F5/09/P/2013 of January 27, 2014) and by the National Science Centre (NCN) (Grant no. 2013/09/B/HS2/02763). The authors wish to thank the anonymous reviewers for their helpful comments and suggestions. A special thank you goes to Colin Phillips from the University of Maryland for discussing several issues considered in this paper with us.

\section{References}

Allen Mark, Bedecker William, Osterhout Lee (2003). Morphological analysis in sentence processing: An ERP study. Language and Cognitive Processes 18(1), 405430.

BAder Markus, Meng Michael (1999). Case attraction phenomena in German. Manuscript,UniversityofJena.URL:http://citeseerx.ist.psu.edu/viewdoc/download?doi= 10.1.1.112.2979\&rep=rep1\&type=pdf [accessed August 28, 2018].

Bader Markus, Meng Michael, BAyer Josef (2000). Case and reanalysis. Journal of Psycholinguistic Research 29, 37-52.

Baggio Giosuè (2004). Two ERP Studies on Dutch Temporal Semantics. MA thesis, University of Amsterdam.

BAgGio Giosuè (2008). Processing temporal constraints: An ERP study. Language Learning 58, 35-55.

BŁaszczak Joanna (2019). Be future”- Old and Modern Views on FUTURE: Typological, Diachronic and Psycholinguistic Aspects. Poznań: Adam Mickiewicz University Press

BŁaszczak Joanna, JabŁońska Patrycja, Klimek-Jankowska Dorota, Migdalski Krzyszytof (2014). The riddle of future tense in Polish: How much 'future' is there in 'future tense'? In Future Tense(s) / Future Time(s), Philippe De Brabanter, Mikhail Kissine, Saghie Sharifzadeh (eds.), 165-204. Oxford: Oxford University Press.

Bock Kathryn, Miller Carol A. (1991). Broken agreement. Cognitive Psychology 23, 45-93.

Bos Laura S., Dragoy Olga, Stowe Laurie A., Bastiaanse Roelien (2013). Time reference teased apart from tense: Thinking beyond the present. Journal of Neurolinguistics 26, 283-297.

Clifton Charles Jr., Frazier Lyn, Deevy Patricia (1999). Feature manipulation in sentence comprehension. Rivista di Linguistica 11, 11-39.

Dahl Östen, Velupillai Viveka (2011). Chapter 67: The future tense. In The World Atlas of Language Structures (WALS) Online, Matthew S. DrYER, Martin Haspelmath (eds.). Munich: Max Planck Digital Library.

Dillon Brian, Nevins Andrew, Austin Alison C., Phillips Colin (2012). Syntactic and semantic predictors of tense in Hindi: An ERP investigation. Language and Cognitive Processes 27(3), 313-344. 
Drenhaus Heiner, Frisch Stefan, SAddy Douglas (2005). Processing negative polarity items: When negation comes through the backdoor. In Linguistic Evidence: Empirical, Theoretical, and Computational Perspectives (= Studies in Generative Grammar 85), Stephan KePSER and Marga ReIs (eds.), 145-165. Berlin: de Gruyter.

Fisiak Jacek, LipińsKa-Grzegorek Maria, Zabrocki Tadeusz (1978). An Introductory English-Polish Contrastive Grammar. Warszawa: Państwowe Wydawnictwo Naukowe.

HäUssler Jana (2012). The Emergence of Attraction Errors during Sentence Comprehension. PhD thesis, University of Konstanz (revised version for publication).

HAGOoRT Peter (2003). Interplay between syntax and semantics during sentence comprehension: ERP effects of combining syntactic and semantic violations. Journal of Cognitive Neuroscience 15, 883-899.

KAAN Edith (2007). Event-related potentials and language processing: A brief overview. Language and Linguistics Compass 1(6), 571-591.

Lewis Shevaun, Phillips Colin (2015). Aligning grammatical theories and language processing models. Journal of Psycholinguistic Research 44(1), 27-46.

Molinaro Nicola, Kim Albert, Vespignani Francesco, Joв Remo (2008). Anaphoric agreement violation: An ERP analysis of its interpretation. Cognition 106, 963-974.

Newman Aaron J., Ullman Michael T., Pancheva Roumyana, Waligura Diane L., Neville Helen J. (2007). An ERP study of regular and irregular English past tense inflection. Neuroimage 34, 435-445.

Osterhout Lee, Holсомв Phillip J. (1992). Event-related brain potentials elicited by syntactic anomaly. Journal of Memory and Language 31, 785-806.

Osterhout Lee, Nicol Janet (1999). On the distinctiveness, independence, and time course of the brain responses to syntactic and semantic anomalies. Language and Cognitive Processes 14(3), 283-317.

Parker Dan, Phillips Colin (2016). Negative polarity illusions and the format of hierarchical encodings in memory. Cognition 157, 321-339.

Pearlmutter Neal J. (2000). Linear versus hierarchical agreement feature processing in comprehension. Journal of Psycholinguistic Research 29, 89-98.

Pearlmutter Neal J., Garnsey Susan M., Bock Kathryn (1999). Agreement processes in sentence comprehension. Journal of Memory and Language 41, 427-456.

Phillips Colin, WAgers Matthew W., LAU Ellen F. (2011). Grammatical illusions and selective fallibility in real-time language comprehension. In Experiments at the Interfaces (= Syntax and Semantics 37), Jeffrey T. Runner (ed.), 153-186. Bingley: Emerald.

Przepiórkowski Adam, Bańko Mirosław, Górski Rafał L., Lewandowska-TomaszCZyk Barbara (2012). Narodowy Korpus Języka Polskiego [The National Corpus of Polish]. Warszawa: Wydawnictwo Naukowe PWN. (Available at: http://nkjp.pl).

Slioussar Natalia, Malko Anton (2016). Gender agreement attraction in Russian: Production and comprehension evidence. Frontiers in Psychology 7, 1651.

Steinhauer Karsten, Ullman Michael T. (2002). Consecutive ERP effects of morpho-phonology and morpho-syntax. Brain and Language 83, 62-65.

Townsend David J., BEVER Thomas G. (2001). Sentence Comprehension: The Integration of Habits and Rules. Cambridge, MA: MIT Press. 
Vasishth Shravan, Brüssow Sven, Lewis Richard L., Drenhaus Heiner (2008). Processing polarity: How the ungrammatical intrudes on the grammatical. Cognitive Science 32, 685-712.

Wagers Matthew W., Lau Ellen F., Phillips Colin (2009). Agreement attraction in comprehension: Representations and processes. Journal of Memory and Language 61, 206-237.

Wellwood Alexis, Pancheva Roumyana, Hacquard Valentine, Phillips Colin (2018). The anatomy of a comparative illusion. Journal of Semantics 35(3), 543-583.

Xiang Ming, Dillon Brian, Phillips Colin (2009). Illusory licensing effects across dependency types: ERP evidence. Brain and Language 108(1), 40-55.

ZHANG Yaxu, ZHANG Jingting (2008). Brain responses to agreement violations of Chinese grammatical aspect. NeuroReport 19(10), 1039-1043.

Joanna Błaszczak

Uniwersytet Wrocławski

Wydział Filologiczny

Instytut Filologii Angielskiej

ul. Kuźnicza 22

50-138 Wrocław

joanna.blaszczak(at)uwr.edu.pl

Juliane Domke

Forschungsgruppe Soziale Neurowissenschaften

Max-Planck-Gesellschaft

Campus Nord, Haus 5

Humboldt-Universität zu Berlin

Philippstrasse 13

10099 Berlin

juliane.domke(at)gmail.com 